\title{
ANALISIS RISIKO KREDIT ANGSURANSISTEM FIDUSIA PADA PERUM PEGADAIAN CABANG PRAYA LOMBOK TENGAH
}

\author{
I Nyoman Nugraha Ardana Putra ${ }^{1}$, Bq. Nurul suryawati ${ }^{2}$, \\ Desi Prapita Sari ${ }^{3}$ \\ ${ }^{I}$ Fakultas Ekonomi Dan Bisnis Universitas Mataram,ibobid@yahoo.com \\ ${ }^{2}$ Fakultas Ekonomi Dan Bisnis Universitas Mataram,bqsuryawati@gmail.com \\ ${ }^{3}$ Fakultas Ekonomi Dan Bisnis Universitas Mataram, desyprapita@yahoo.com
}

\begin{abstract}
ABSTRAK
Penelitian ini berjudul "Analisis Risiko Kredit Angsuran Sistem Fidusia Pada PT. Pegadaian (Persero) Cabang Praya Lombok Tengah”. Tujuan Penelitian ini adalah untuk mengetahui bagaimana tingkat risiko kredit angsuran sistem fidusiayang dihadapi oleh Pegadaian Cabang Praya Lombok Tengahselama lima tahun terakhir yaitu dari tahun 2012 sampai dengan 2016. Pengumpulan data yang dilakukan adalah metode studi kasus. Jenis penelitian yang digunakan adalah penelitian deskriptif, dalam hal ini bagian yang akan dijelaskan/dideskripsikan adalah tingkat risiko kredit angsuran sistem fidusia padaPegadaian Cabang Praya Lombok Tengah. Variabel yang yang digunakan dalam penelitian ini terdiri dari Nilai Risiko (Value at Risk/VaR), Hasil Ekspektasi (Expected Return), Risiko Kredit (Total Risk).

Berdasarkan hasil analisis data dengan menggunakan VaR, maka hipotesispenelitian yang menyatakan tingkat risiko kredit angsuran sistem fidusia yang dihadapi oleh Pegadaian Cabang Praya Lombok Tengah tergolong tinggi dapat dibuktikan. Pernyataan ini didukung oleh temuan penelitian, yaitu nilai kerugian maksimum yang dihadapi Pegadaian Cabang Praya Lombok Tengah pada tahun 2016 dengan tingkat keyakinan 99 persen adalah sebesar Rp.115.317.868, dimana nilai relatifnya sebesar 14,19 persen masih lebih besar jika dibandingkan dengan annual interest sebesar 13,80 persen.

Kata kunci: Analisis Risiko, Kredit, Sistem Fidusia
\end{abstract}

\begin{abstract}
This research entitled "Credit Risk Analysis Installment Fiduciary System At PT. Pawnshop (Persero) Central Lombok Praya Branch ". The purpose of this study is to find out how the level of credit risk installment fiduciary system faced by Pawnshop Praya Central Lombok Branch for the last five years ie from 2012 until 2016.Data collection is a case study method. The type of research used is descriptive research, in this case the section will be described / described is the level of credit risk installment fiduciary system at Pawnshop Central Praya Lombok Central. The variables used in this study consist of Value at Risk (VaR), Expected Return, Credit Risk (Total Risk).

Based on the results of data analysis using VaR, the hypothesis of research stating the level of credit risk installment fiduciary system faced by Praya Branch Praya Central Lombok high classified can be proven. This statement is supported by the research findings, namely the maximum loss value encountered by Praya Central Praya Branch Central Lombok in 2016 with 99 percent confidence level is Rp.115.317.868, where the relative value of 14.19 percent is still greater when compared with the annual interest amounting to 13.80 percent.
\end{abstract}

Keywords: Risk Analysis, Credit, Fiduciary System 


\section{PENDAHULUAN}

Dalam kehidupan sehari-hari, uang selalu saja dibutuhkan untuk membeli, membayar berbagai keperluan. Sumber masalah yang terjadi disini adalah terkadang kebutuhan yang ingin dibeli tidak dapat dicukupi dengan uang yang dimilikinya. Jika sudah demikian, maka mau tidak mau kita akan mengurangi untuk membeli berbagai keperluan yang dianggap tidak penting, namun untuk keperluan yang sangat penting terpaksa harus dipenuhi dengan berbagai cara seperti meminjam dari berbagai sumber dana yang ada (Kasmir, 2010).

Jika kebutuhan dana jumlahnya besar, maka dalam jangka pendek sulit dipenuhi, apalagi jika harus lewat lembaga perbankan. Jika dana yang relatif kecil tidak jadi masalah, karena banyak tersedia sumber dana yang murah dan cepat, mulai dari pinjaman di tetangga, tukang ijon, sampai pinjaman dari berbagai lembaga keuangan lainnya. Bagi mereka yang memiliki barang-barang berharga, kesulitan dana dapat segera terpenuhi dengan cara menjual barang berharga tersebut, sehingga jumlah uang yang diinginkan dapat terpenuhi. Tetapi, risikonya barang yang telah dijual akan hilang dan sulit untuk kembali (Jorion, 2001). Kesulitan-kesulitan yang timbul tersebut dapat diatasi dengan memenuhi kebutuhan dana tanpa takut kehilangan barang-barang berharga, maka masyarakat dapat menjaminkan barang-barangnya ke lembaga tertentu. Barang yang dijaminkan tersebut pada waktu tertentu dapat ditebus kembali setelah masyarakat melunasi pinjamannya (Raymond, 2000).

Salah satu BUMN yang dijadikan sebagai pilar ekonomi negara yaitu Pegadaian. Pegadaian adalah salah satu BUMN di Indonesia yang usaha intinya adalah bidang jasa penyaluran kredit kepada masyarakat atas dasar hukum gadai. Tujuan utama usaha Pegadaian adalah untuk mengatasi agar masyarakat yang sedang membutuhkan uang tidak jatuh ke tangan pelepas uang atau rentenir. Keuntungan lainnya adalah pihak Pegadaian tidak mempermasalahkan untuk apa uang tersebut digunakan dan hal ini tentu saja bertolak belakang dengan pihak perbankan yang harus membuat serinci mungkin tentang penggunaan. Begitu pula dengan sanksi yang diberikan relatif ringan, apabila tidak dapat melunasi dalam waktu tertentu. Sanksi yang paling berat adalah jaminan yang disimpan akan dilelang untuk menutupi kekurangan pinjaman yang telah diberikan.

Berdasarkan pada latar belakang, maka dapat diidentifikasi permasalahan sebagai berikut: 1 . Adanya selisih lebih antara target piutang yang direncanakan dengan piutang yang dapat direalisasikan. 2.Tingginya jumlah piutang tak tertagih setiap tahunnya pada Pegadaian Cabang Praya Lombok Tengah sehingga berpengaruh pada risiko kredit yang dihadapi. Melalui identifikasi masalah tersebut, dapatlah dirumuskan permasalahan yang akan menjadi dasar penelitian ini adalah "Bagaimanakah tingkat risiko kredit angsuran sistem fidusia yang dihadapi Pegadaian Cabang Praya Lombok Tengah. “

\section{TUJUAN :}

Berdasarkan latar belakang dan rumusan masalah tersebut dapat disusun tujuan penelitian sebagai berikut:

"Untuk mengetahui tingkat risiko kredit angsuran sistem fidusia pada Pegadaian Cabang Praya Lombok Tengah”. 


\section{KERANGKA TEORITIS:}

Penelitian ini membahas tentang Risiko kredit pada Pegadaian Cabang Praya Lombok Tengah, oleh karena itu perlu dibentuk suatu kerangka teori pemikiran yang dapat mempermudah dalam memahami seluruh rangkaian penelitian.

\begin{tabular}{|c|}
\hline $\begin{array}{c}\text { Pegadaian Cabang Praya } \\
\text { Lombok Tengah }\end{array}$ \\
\hline Laporan Keuangan \\
- Neraca \\
- Laba rugi \\
\hline Piutang Angsuran Sistem \\
Fidusia \\
\hline
\end{tabular}

Gambar 1. Kerangka Konseptual Penelitian

\section{METODE PENILITIAN}

Jenis penelitian yang digunakan adalah deskriptif. Metode ini adalah suatu metode penelitian dalam meneliti kasus sekelompok manusia, suatu obyek, suatu set kondisi, suatu sistem pemikiran, atau suatu peristiwa pada masa sekarang yang bertujuan untuk membuat suatu deskripsi, gambaran, atau lukisan secara sistimatis, faktual dan akurat mengenai fakta-fakta, sifat-sifat, serta hubungan antar fenomena yang diteliti (Nazir, 1999:63). Dalam hal ini, bagian yang akan dijelaskan/dideskripsikan adalah tingkat risiko kredit angsuran sistem fidusia pada Pegadaian Cabang Praya Lombok Tengah.

Metode pengumpulan data yang digunakan dalam penelitian ini adalah metode studi kasus yang terjadi pada Pegadaian Cabang Praya Lombok Tengah. Studi kasus atau penelitian kasus (case study), adalah penelitian tentang kasus subyek penelitian yang berkenaan dengan suatu fase spesifik atau khas dari keseluruhan personalitas. Subyek penelitian dapat saja individu, kelompok, lembaga maupun masyarakat (Nazir,1999:66). Studi kasus yang akan dibahas dalam penelitian ini adalah tingkat risiko kredit angsuran sistem fidusia pada Pegadaian Cabang Praya Lombok Tengah.

Teknik pengumpulan data yang digunakan dalam penelitian ini adalah: wawancara dan dokumentasi. Wawancara yaitu dengan mengadakan tanya jawab secara langsung dengan karyawan dan manajer pegadaian, yang berpedoman pada daftar pertanyaan yang disiapkan sebelumnya. Dokumentasi merupakan pengumpulan data dan bukti tertulis seperti laporan keuangan yang terdiri dari neraca dan laporan rugi laba. Dokumentasi merupakan cara pengumpulan data dengan melakukan pencatatan terhadap data yang telah disediakan oleh Pegadaian Cabang Praya Lombok Tengah. Data yang dibutuhkan terdiri dari:

a) Data hasil perkembangan piutang Pegadaian Cabang Praya Lombok Tengah tahun 2012 - 2016.

b) Data laporan laba rugi pada Pegadaian Cabang Praya Lombok Tengah tahun 20122016.

c) Data laporan neraca Pegadaian Cabang Praya Lombok Tengah tahun 2012 - 2016. 


\section{ANALISIS DATA}

\section{Identifikasi dan Definisi Operasional Variabel}

1. Identifikasi Variabel

Variabel yang dibutuhkan untuk pengujian hipotesis yang dirumuskan dalam penelitian yaitu:

1) Nilai Risiko (Value at Risk/VaR)

2) Hasil Ekspektasi (Expected Return)

3) Risiko Kredit (Total Risk)

2. Definisi Operasional Variabel

1) Nilai risiko adalah pengukuran risiko yang dihitung dengan estimasi persentase kerugian potensial usaha kredit melalui VaR nilai absolut dan nilai relatif pada Pegadaian Cabang Praya Lombok Tengah.

a) Nilai VaR absolut adalahkerugian terhadap zero (nol) pada Pegadaian Cabang Praya Lombok Tengah, dimana dalam perhitungannya menggunakan metode matriks yang dikalikan dengan dua parameter kuantitatif yaitu tingkat kepercayaan (confidence level) dan horizon waktu disebabkan sifat pengukurannya adalah estimasi.

b) Nilai VaR relatif adalah kerugian yangdibandingkan dengan rata-rata nilai pengembalian hasil yang diharapkan (expected return) oleh Pegadaian Cabang Praya Lombok Tengah. Perhitungannya menggunakan metode matriks yang dikalikandengan dua parameter kuantitatif yaitu tingkat kepercayaan (confidence level) danhorizon waktu disebabkan sifat pengukurannya adalah estimasi.

2) Tingkat pengembalian hasil yang diharapkan (expected return) digunakan untuk mengukur rata-rata estimasi atau perkiraan dari distribusi probabilitas yang diperoleh dari pendapatan nilai profit (return) kredit angsuran sistem fidusia pada Pegadaian Cabang Praya Lombok Tengah. Terkait dengan penelitian ini, tingkat pengembalian hasil yang diharapkan dihitung dari variabel nilai rata-rata equivalent rate atau distribusi pendapatan kredit angsuran sistem fidusia dari periode bulanan dalam setahun (tahun 2016).

3) Standar deviasi (total risk) menunjukkan bahwa jika semakin besar standar deviasi dari pengembalian hasil, maka semakin besar variabel dari pengembalian hasil dansemakin tinggi risiko dari investasi kredit pada Pegadaian Cabang Praya Lombok Tengah. Hal ini dapat digunakan sebagai ukuran absolut dari variabilitas pengembalian hasil. Dalam aplikasi penelitian ini, risiko investasi kredit angsuran sistem fidusia dapat dilihat secara total (total risk) melalui standar deviasi. Dimana standar deviasi mengukur persentase ukuran jarak atau fluktuasi dari variabel rata-rata nilai pengembalian hasil yang diharapkan. Pada aplikasinya, standar deviasi adalah jumlah kuadrat variable nilai equivalent rate (distribusi pendapatan kredit angsuran sistem fidusia) dikurangi variabel nilai rata-rata (mean) equivalent rate kredit angsuran sistem fidusia dibagi jumlah periode waktu bulanan dalam setahun.

\section{Prosedur Analisis}

1. Analisis Deskriptif

Analisis data berupa analisis deskriptif digunakan untuk mengetahui prosedur pengelolaan kredit bermasalah dan perkembangan kolektibilitas kredit 
sehingga mudah untuk dipresentasikan. Penilaian menggunakan data per Desember 2016. Dalam perhitungan terhadap nilai risiko di masa yang akan datang tidak bisa memastikan dengan pasti potensi kerugian yang akan terjadi. Oleh sebab itu, peluang selalu mengikut hasilnya.

2. Value at Risk (VaR)

Salah satu alat analisis yang digunakan untuk menghitung risiko kredit adalah VaR. VaR dapat mengetahui berapa jumlah risiko maksimum yang akan dialami Pegadaian Cabang Praya Lombok Tengah. Tahapan dalam menghitung VaR adalah sebagai berikut:

1) Menentukan matriks transisi bulanan

Matriks transisi bulanan merupakan rating debitur baik, meningkat, menurun atau tetap (perubahan dari migrasi kualitas kredit pada suatuperiode waktu tertentu). Matriks transisi ini berukuran 4 x 4 karenajumlah kelas (grade) dalam credit rating system ada empat yaitu lancar, kurang lancar, diragukan, dan macet.

2) Menentukan matriks migrasi unconditional

Matriks migrasi unconditional adalah proporsi perpindahan kolektibilitassatu bulan ke bulan berikutnya. Bentuk matriks ini sama dengan matrikstransisi.

\begin{tabular}{l|llll}
\cline { 2 - 5 } \multicolumn{1}{c|}{} & $\mathrm{L}$ & $\mathrm{KL}$ & $\mathrm{D}$ & $\mathrm{M}$ \\
$\mathrm{L}$ & $\mathrm{P} 11$ & $\mathrm{P} 12$ & $\mathrm{P} 13$ & $\mathrm{P} 14$ \\
$\mathrm{KL}$ & $\mathrm{P} 21$ & $\mathrm{P} 22$ & $\mathrm{P} 23$ & $\mathrm{P} 24$ \\
$\mathrm{D}$ & $\mathrm{P} 31$ & $\mathrm{P} 32$ & $\mathrm{P} 33$ & $\mathrm{P} 34$ \\
$\mathrm{M}$ & $\mathrm{P} 41$ & $\mathrm{P} 42$ & $\mathrm{P} 43$ & $\mathrm{P} 44$
\end{tabular}

Baris ke satu pada matriks di atas merupakan peluang untukmenghitung VaR pada kolektibilitas lancar. Baris ke dua merupakanpeluang untuk menghitung VaR pada kolektibilitas kurang lancar, dan seterusnya.

Keterangan:

a) P11 adalah peluang kredit dengan peringkat 1 (kolektibilitas lancar) tetap berada pada peringkat 1 (kolektibilitas lancar).

b) P12 adalah peluang kredit dengan peringkat 1 (kolektibilitas lancar) menjadi berada pada peringkat 2 (kolektibilitas kurang lancar) danseterusnya.

c) L, KL, D, dan M adalah kolektibilitas lancar, kurang lancar, diragukan, dan macet.

Menurut Putra (2012) kredit bermasalah disatu sisi meningkatkan biaya operasional namun disisi lain justru meningkatkan pendapatan, maka bisa berdampak merugikan dan harus dikelola dengan baik. Putra (2013) juga menyatakan kredit bermasalah juga salah satu kinerja dalam bentuk pengawasan lembaga pembiayaan.

3) Menghitung rata-rata nilai baki debet

Rata-rata nilai ini merupakan jumlah dari hasil perkalian antara peluang migrasi ke peringkat tertentu dengan hasil kali antara nilai baki debettotal peringkat tertentu pada akhir periode pengamatan dengan peluangperingkat tertentu. Peringkat yang dimaksud adalah kolektibilitas. Secara sistematis dapat dirumuskan sebagai berikut: 
Keterangan:

$$
\mu \text { total }=\sum^{\mathrm{s}_{\mathrm{i}}}=1 \text { pi } \mu \mathrm{i}
$$

a) $\mu$ total adalah rata-rata nilai baki debet pada tahun 2016 .

b) pi adalah peluang suatu kondisi (peluang migrasi ke peringkattertentu) dari $\mathrm{L}$ ke L, L ke KL, L ke D, L ke M. Dari KL ke L, KLtetap KL, KL ke D, KL ke $\mathrm{M}$, dan seterusnya.

c) $\mu \mathrm{i}$ adalah nilai baki debet yang merupakan hasil kali antara bakidebet total dengan peringkat tertentu pada akhir periode pengamatandengan peluang peringkat tertentu.

d) s adalah banyaknya peringkat (L, KL, D, M).

4) Menghitung selisih nilai baki debet dengan nilai rata-rata debet $(\mu$ total).

5) Menghitung ragam, yaitu jumlah dari hasil rata-rata perkalian kuadratselisih rata-rata nilai baki debet dengan rata-rata terbobot denganpeluangnya. Rumus untuk menghitung ragam adalah:

$$
\delta^{2}=\sum^{s_{i}}=0 \text { pi } \boldsymbol{\mu i}^{2}-\mu \text { total }^{2}
$$

6) Menghitung simpangan baku yang merupakan akar dari ragam. Simpangan baku disebut volatilitas. Nilai volatilitas digunakan untukmenghitung VaR kredit dengan asumsi nilai pinjaman terdistribusinormal untuk tingkat keyakinan 95 persen dan 99 persen adalah:

$$
\mathbf{V a R}=\mathbf{Z a} \times \boldsymbol{\delta}
$$

Keterangan:

a) $\mathrm{Z} \alpha$ adalah titik kritis pada tabel $\mathrm{Z}$ ( $\mathrm{Z} \alpha$ pada tingkat keyakinantertentu).

b) $\delta$ adalah pendugaan volatilitas, semakin besar tingkat kepercayaan yang digunakan maka nilai VaRakan semakin besar, begitu pula dengan volatilitas, semakin besarvolatilitas yang dihasilkan maka nilai VaR akan semakin besar pula. Tingkat keyakinan 95 persen digunakan oleh Morgan "Risk Metrics"dan tingkat keyakinan 99 persen digunakan oleh Basel Committee.

Analisis VaR diawali dengan menentukan matriks transisi bulanan. Matriks transisi diperoleh dari Bulan Januari 2016 sampai dengan Bulan Desember 2016 sehingga matriks transisi yang dihasilkan sebanyak 11 matriks yang berukuran $4 \mathrm{x} 4$. Matriks transisi yang diperoleh dijumlahkan kemudian dicari rata-ratanya dan dari ratarata yang diperoleh digunakan untuk menyusun matriks unconditional

\section{HASIL DAN PEMBAHASAN}

Tabel 1. Jumlah Kredit Fidusia Berdasarkan Tingkat Kolektibilitasnya pada Pegadaian Cabang Praya Lombok Tengah Periode Tahun 2016

\begin{tabular}{|c|l|c|c|c|c|c|}
\hline No. & Bulan & $\begin{array}{c}\text { Total Kredit } \\
(\mathbf{R p})\end{array}$ & $\begin{array}{c}\text { Lancar } \\
(\mathbf{R p})\end{array}$ & $\begin{array}{c}\text { Kurang } \\
\text { Lancar } \\
(\mathbf{R p})\end{array}$ & $\begin{array}{c}\text { Diragukan } \\
(\mathbf{R p})\end{array}$ & $\begin{array}{c}\text { Macet } \\
\text { (Rp) }\end{array}$ \\
\hline 1 & Januari & 765.640 .000 & 387.100 .000 & 189.270 .000 & 75.708 .000 & 113.562 .000 \\
\hline 2 & Februari & 785.604 .000 & 393.100 .000 & 192.252 .000 & 86.100 .800 & 114.151 .200 \\
\hline 3 & Maret & 788.150 .000 & 386.608 .000 & 192.771 .000 & 88.108 .400 & 120.662 .600 \\
\hline 4 & April & 808.710 .000 & 386.035 .000 & 196.337 .500 & 98.535 .000 & 127.802 .500 \\
\hline 5 & Mei & 809.330 .000 & 405.390 .000 & 179.970 .000 & 92.988 .000 & 130.982 .000 \\
\hline 6 & Juni & 809.850 .000 & 403.260 .000 & 173.295 .000 & 93.318 .000 & 139.977 .000 \\
\hline
\end{tabular}




\begin{tabular}{|c|l|c|c|c|c|c|}
\hline No. & Bulan & $\begin{array}{c}\text { Total Kredit } \\
(\mathbf{R p})\end{array}$ & $\begin{array}{c}\text { Lancar } \\
(\mathbf{R p})\end{array}$ & $\begin{array}{c}\text { Kurang } \\
\text { Lancar } \\
(\mathbf{R p})\end{array}$ & $\begin{array}{c}\text { Diragukan } \\
(\mathbf{R p})\end{array}$ & $\begin{array}{c}\text { Macet } \\
(\mathbf{R p})\end{array}$ \\
\hline 7 & Juli & 817.600 .000 & 412.626 .000 & 171.987 .000 & 92.794 .800 & 140.192 .200 \\
\hline 8 & Agustus & 823.510 .000 & 402.871 .000 & 175.319 .500 & 94.127 .800 & 151.191 .700 \\
\hline 9 & September & 828.550 .000 & 401.068 .000 & 188.741 .000 & 85.496 .400 & 153.244 .600 \\
\hline 10 & Oktober & 835.590 .000 & 426.330 .000 & 182.130 .000 & 71.852 .000 & 155.278 .000 \\
\hline 11 & November & 839.760 .000 & 448.270 .000 & 160.745 .000 & 76.298 .000 & 154.447 .000 \\
\hline 12 & Desember & 840.765 .000 & 485.087 .000 & 157.839 .000 & 41.135 .600 & 156.703 .400 \\
\hline & Rata-rata & 812.754 .917 & 411.478 .750 & 180.054 .750 & 83.038 .567 & 138.182 .850 \\
\hline & Proporsi & $100 \%$ & $50,628 \%$ & $22,154 \%$ & $10,217 \%$ & $17,002 \%$ \\
\hline
\end{tabular}

Sumber: Lampiran 1.

Berdasarkan Tabel 1. di atas dapat diketahui bahwa rata-rata kredit yang disalurkan Pegadaian Cabang PrayaLombok Tengah selama tahun 2016 sampai sebesar Rp. 812.754.917. Sebanyak 50,628 persen jumlah kredit yang disalurkan termasuk dalam kategori kolektibilitas lancar, sedangkan kredit bermasalah didominasi oleh kolektibilitas kurang lancar sebesar 22,154 persen, kemudian kolektibilitas macet sebesar 17,002 persen, diikuti kolektibilitas diragukan yang menempati proporsi terendah yaitu sebesar 10,217 persen. Jika diperhatikan maka terdapat sebanyak 49,372 persen yang berpotensi menjadi risiko kerugian bagi kelangsungan usaha kredit Pegadaian Cabang Praya Lombok Tengah.

\section{ANALISIS DATA PEMBAHASAN}

Matriks unconditional merupakan proporsi perubahan kolektibilitas debitur per bulan. Dengan matriks unconditional dapat diketahui peluang perubahan kolektibilitas debitur tiap bulan yang dapat dilihat dari perubahannominal baki debet tiap bulannya. Matriks transisi bulanan yang diperoleh sebanyak 11 matriks yang berukuran $4 \mathrm{x} 4$, dimana detail matriks transisi bulanan ini dapat dilihat pada Lampiran 2. Matriks migrasi unconditional rata-rata yang dihasilkan adalah:

Tabel 2. Matriks Migrasi Unconditional Rata-rata Kolektibilitas Kredit Fidusia pada Pegadaian Cabang Praya Lombok Tengah Tahun 2016

\begin{tabular}{|c|c|c|c|c|}
\hline Kategori & $\mathbf{L}$ & $\mathbf{K L}$ & $\mathbf{D}$ & $\mathbf{M}$ \\
\hline $\mathrm{L}$ & 0,00225 & 0,00165 & 0,01443 & 0,00117 \\
\hline $\mathrm{KL}$ & 0,00154 & 0,00257 & 0,00883 & 0,00102 \\
\hline $\mathrm{D}$ & 0,00380 & 0,00249 & 0,02979 & 0,00164 \\
\hline $\mathrm{M}$ & 0,00165 & 0,00102 & 0,00998 & 0,00095 \\
\hline
\end{tabular}

Sumber: Lampiran 2.

Keterangan:
$\mathrm{L}=$ Lancar
$\mathrm{D}=$ Diragukan
$\mathrm{KL}=$ Kurang Lancar
$\mathrm{M}=$ Macet

Matriks di atas menunjukkan bahwa peluang kolektibilitas lancar untuktetap bertahan pada posisinya adalah sebesar 0,225 persen. Nilai ini menunjukkanbahwa debitur yang memiliki kolektibilitas lancar memiliki peluang yang sangat kecil untuk tetap menjadi debitur yang dapat melaksanakan kewajibannya dalam membayar 
angsuran kredit dengan baik. Namun debitur kolektibilitas lancarmemiliki peluang sebesar 0,165 persen untuk dapat menjadi debitur dengan kolektibilitas kurang lancar.

Baki debet kredit (outstanding) adalah saldo rekening yang menunjukkan posisi hutang nasabah pada saat tertentu. Nilai baki debet untuk kolektibilitas Lancar (L), Kurang Lancar (KL), Diragukan (D), dan Macet (M) dapat dilihat pada Tabel 3.

Tabel 3. Rata-rata Baki Debet Tiap Kolektibilitas Kredit pada Pegadaian Cabang Praya Lombok Tengah Selama Tahun2016

\begin{tabular}{|l|c|c|}
\hline \multicolumn{1}{|c|}{ Kolektibilitas } & $\begin{array}{c}\text { Baki Debet } \\
\text { (Rp) }\end{array}$ & $\begin{array}{c}\text { Persentase } \\
(\mathbf{\%})\end{array}$ \\
\hline Lancar & 411.478 .750 & 50,628 \\
\hline KurangLancar & 180.054 .750 & 22,154 \\
\hline Diragukan & 83.038 .567 & 10,217 \\
\hline Macet & 138.182 .850 & 17,002 \\
\hline Total & 812.754 .917 & 100 \\
\hline
\end{tabular}

Sumber: Lampiran 3.

Berdasarkan tabel nilai baki debet untuk kolektibilitas L, KL, D, dan M pada Pegadaian Cabang Praya Lombok Tengah didominasi oleh kolektibilitas lancar sebesar 50,628 persen yaitu sejumlah Rp.411.478.750, sedangkan proporsi terendah ditempati oleh kolektibilitas diragukan sebesar 10,217 persen yaitu sejumlah Rp.83.038.567. Tingkat keyakinan yang digunakan dalampenelitian ini adalah 95 persen dan 99 persen. Alasanya adalah karena J.P. Morgan Risk Metrics biasa menggunakan tingkat keyakinan 95 persen, sedangkan Basel Comitte menggunakan tingkat keyakinan 99 persen.

Nilai VaR merupakan nilai kerugian maksimum yang dapat dialami olehPegadaian untuk periode satu tahun pada tingkat keyakinan yang telah ditentukan. Tingkat keyakinan yang digunakan pada penelitian ini adalah 95 persen dan 99persen. Dengan mengetahui nilai VaR pada kredit yang disalurkan maka akan diketahui berapa jumlah kerugian maksimum yang dapat dialami Pegadaian sehingga dapat dilakukan pengelolaan risiko kredit yang sesuai. Tabel berikut menunjukkan kerugian maksimum yang dialami Pegadaian Cabang Praya Lombok Tengah.

Tabel 4. VaR Produk Kredit pada Pegadaian Cabang Praya Lombok Tengah Tahun 2016

\begin{tabular}{|l|c|c|c|}
\hline \multicolumn{1}{|c|}{ Kolektibilitas } & Volatilitas & Var $\boldsymbol{\alpha}=\mathbf{5 \%}$ & Var $\boldsymbol{\alpha}=\mathbf{1 \%}$ \\
\hline Lancar & $12.377 .353,26$ & $20.422 .632,88$ & $28.839 .233,10$ \\
\hline Kurang Lancar & $12.390 .920,20$ & $20.445 .018,34$ & $28.870 .844,08$ \\
\hline Diragukan & $12.330 .185,79$ & $20.344 .806,55$ & $28.729 .332,89$ \\
\hline Macet & $12.394 .188,32$ & $20.450 .410,73$ & $28.878 .458,79$ \\
\hline \multicolumn{2}{|l|}{ Total } & $81.662 .868,51$ & $115.317 .868,86$ \\
\hline
\end{tabular}

Sumber: Lampiran 4.

Nilai volatilitas merupakan perubahan keragaman faktor risiko. Volatilitas menunjukkan fluktuasi nilai di masa lalu sehingga volatilitas dapatmenunjukkansebaran munculnya peluang terjadinya risiko kredit yang terjadi di Pegadaian Cabang Praya Lombok Tengah. VaR kredit pada kolektibilitas lancar memperlihatkan bahwabesarnyakemungkinan kerugian maksimum yang dihadapi Pegadaian Cabang Praya Lombok Tengah dengan tingkat keyakinan 95 persen pada tahun 2016 adalah sekitar Rp. 20.422.632. Nilai tersebut adalah 4,96 persen dari baki debet pinjaman 
kolektibilitas lancar, sedangkan kemungkinan maksimum dengan keyakinan 99 persen adalah sekitarRp. 28.839.233 atau sebesar 7,01persen dari baki debet pinjaman kolektibilitas lancar. Nilai VaR pada kolektibilitas lancar digunakan sebagai estimasi pergeseran kolektibilitas lancar ke kolektibilitas lainnya. Estimasi ini digunakan untuk perkiraan di masa yang akan datang apabila debitur kolektibilitas lancar bergeser ke kolektibilitas lainnya.

Berdasarkan hasil analisis data dengan menggunakan VaR, maka jelas tingkat risiko kredit angsuran sistem fidusia yang dihadapi oleh Pegadaian Cabang Praya Lombok Tengah tergolong tinggi. Pernyataan ini didukung oleh temuan penelitian, yaitu nilai kerugian maksimum yang dihadapi Pegadaian Cabang Praya Lombok Tengah pada tahun 2016 dengan tingkat keyakinan 99 persen adalah sebesar Rp.115.317.868, dimana nilai relatifnya sebesar 14,19 persen masih lebih besar jika dibandingkan dengan annual interest sebesar 13,80 persen.

Nilai VaR Pegadaian Cabang Praya Lombok Tengah pada tahun 2016 menunjukkan bahwa kredit yang dianggap berisiko mengalami nilai kerugian maksimum terbesar berada pada kolektibilitas macet. Nilai kerugian terbesar pada kolektibilitas macet disebabkan oleh adanya pergeseran kolektibilitas dari kolektibilitas kurang lancar ke kolektibilitas macet yang nilainya lebih besar daripada pergeseran ke kolektibilitas lancar. Kolektibilitas diragukan memiliki kemampuan bergeser yang cukup besar. Hal tersebut menimbulkan kerugian yang cukup besar bagi Pegadaian. Oleh sebab itu Pegadaian Cabang Praya Lombok Tengah harus lebih berkonsentrasi untuk mengelola debitur kolektibilitas kurang lancar agar dapat bergeser ke kolektibilitas yang lebih baik seperti yang disampaikan (Saputra, 2011).Hal ini dapat dilakukan dengan pengawasan serta pembinaan yang intensif.

\section{Implikasi Manajerial Risiko Kredit}

Pegadaian Cabang Praya Lombok Tengah harus memiliki pengelolaan risiko kredit yang baik Seperti yang disampaikan (Wahyudi, 2008) risiko kredit yang terjadi dapat diminimalisir. Melalui Pengelolaan risiko kredit yang baikdan benar dapat menurunkan rasio NPL yang terjadi (Hermanto, 2011). Pengelolaan risiko kredit yang dilakukan oleh Pegadaian Cabang Praya Lombok Tengah yaitu dengan melakukan analisis ulang terhadap nasabah bermasalah menggunakan prinsip $5 \mathrm{C}$ untuk mengetahui character, capital, capability, collateral dan condition.

\section{KESIMPULAN DAN SARAN}

\section{Kesimpulan}

Kerugian maksimum produk kredit yang dihadapi Pegadaian Cabang Praya Lombok Tengah selama tahun 2016 pada tingkat keyakinan 95 persen adalah sekitar Rp. 81.662.868. Nilai kerugian adalah 10,05 persen dari total baki debet di Pegadaian Cabang Praya Lombok Tengah. Pada tingkat keyakinan 99 persen Pegadaian Cabang Praya Lombok Tengahdi tahun 2016 kemungkinan mengalami kerugian maksimum sekitar Rp.115.317.868, dengan nilai relatifnya sebesar 14,19 persen yang masih lebih besar dari nilai annual interest sebesar 13,80 persen. Hal ini sesuai dengan hipotesis yang menyatakan bahwa tingkat risiko kredit angsuran sistem fidusia yang dihadapi oleh Pegadaian Cabang Praya Lombok Tengah tergolong tinggi.

\section{Saran}


Berdasarkan hasil penelitian maka saran yang dapat dilakukan dan diimplementasikan oleh Pegadaian Cabang Praya Lombok Tengah yaitu perlu lebih intensif dalam mengelola risiko kreditnya untuk meminimalikan risiko yang akan dihadapi. Pengelolaan kredit bermasalah yang dapat dilakukan oleh Pegadaian Cabang Praya Lombok Tengahdengan cara sebagai berikut:

1) Penetapan analisis ulang terhadap nasabah bermasalah dengan menggunakan prinsip 5C untuk mengetahui character, capital, capability, collateral dan condition.

2) Melakukan monitoring yang lebih intensif sejak awal penyaluran kredit terhadap usaha nasabah sehingga dapat diketahui perkembangan usaha nasabah.

Melakukan pengawasan dan pembinaan kepada nasabah. Kurangnya pengawasan dan pembinaan terhadap nasabah dapat menimbulkan kesalahan dalam penggunaan kredit oleh nasabah, misalnya kredit yang diajukan oleh nasabah adalah kredit untuk modal kerja tetapi pada kenyataannya kredit digunakan untuk kegiatan konsumtif.

\section{DAFTAR PUSTAKA}

Hermanto. 2011. Analisis Tingkat Risiko Kredit Pada PT. Bank RakyatIndonesia (Persero) Tbk Cabang Sinjai di Kabupaten Sinjai. Fakultas Ekonomi Universitas Hasanuddin. Skripsi dipublikasikan.

Jorion, M. M. 2001. Value at Risk: The New Benchmarking For Managing Finansial Risk. 2nd Edition. Mac Graw-Hill, New Jersey.

Kasmir. 2010. Dasar-Dasar Perbankan. PT. RajaGrafindo Persada. Jakarta

Nazir, Mohammad. 1999. Metode Penelitian. Cetakan Ketiga. GhaliaIndonesia.Jakarta

Putra, INNA, 2012, Kepemilikan Manajerial dan Risiko Kredit Sebagai Pemicu Biaya Keagenan Pada Lembaga Keuangan Mikro, Jurnal Keuangan dan Perbankan, Vol.16 No.3 , 437-444

Putra, INNA, 2013, Perbedaan Profitabilitas DanTingkatPengawasan Sebelum Dan Sesudah Merger Pada Bank Perkreditan Rakyat, Jurnal Keuangan dan Perbankan, Vol. 17, No. 2, 302-309

Raymond P. Kent. 2000. Money and Banking, Holt, Rinehart and Winston, Inc., New York.

Saputra, Lalu Indra. 2011. Analisis Risiko Usaha Kredit Angsuran Sistem Fidusia pada Perum Pegadaian Cabang Gerung Lombok Barat. Fakultas Ekonomi Universitas Mataram. Skripsi tidak dipublikasikan.

Wahyudi, Amen. 2008. Analisis Penyaluran Kredit Perum Pegadaian Di Propinsi Daerah Istimewa Yogyakarta (Periode 2002 - 2006). Fakultas Ekonomi Universitas Islam Indonesia. Skripsi dipublikasikan. 